\title{
BANTUAN HUKUM DAN PENYANTUNAN TERPIDANA PERSPEKTIF SISTEM PERADILAN PIDANA INDONESIA ${ }^{1}$
}

Oleh :

\author{
Eny Heri Manik ${ }^{2}$
}

\begin{abstract}
Every person legal problems with the status as a suspect, accused and convicted person is obliged to secure the protection and legal aid. Legal aid is a right for everyone, especially for those who are punished more than five years is mandatory for legal counsel. Various guarantee protection for legal support in any judicial process is not regulated in the criminal code, Act No. 18 of 2003 regarding advocates, law No. 16 of 2011 on legal aid and law No. 12 of 1996 on corretional services. Began to suspect the examination process stages can have legal counsel or advocate o the court proceedings even to convict the accused. Legal assistance in the Indonesia judiccial process has been set broadly, in the sense that all stages of the judicial process of seeking justice is guaranteed by law without exception, the prisoners declared in the form of sponsorhip such as the availability of legal remedies extensivelly and every level of the judicial process, means remission, leave nearing relase, conditional release, resocialization, assimilation and others. Indonesia criminal justice process is carried out in an integrated manner by law enforcment in the context of a fair process in order to realize the prupose of law is fair, useful and achieving legal certainty for all seekers of justice based on the "system" that has adopted the "Integrated criminal justice system".
\end{abstract}

Keywords : Legal Assistance, Sponsorship Convict, Justice System

\begin{abstract}
Abstrak
Setiap orang tersangkut masalah hukum dengan status sebagai tersangka, terdakwa dan terpidana adalah wajib mendapat perlindungan dan bantuan hukum. Bantuan hukum merupakan hak bagi setiap orang, apalagi bagi mereka yang diancam pidana lebih dari lima tahun adalah wajib untuk didampingi penasehat hukum. Berbagai ketentuan jaminan perlindungan akan bantuan hukum dalam setiap proses peradilan telah diatur dalam KUHAP, UU NO. 18 Tahun 2003 tentang Advokat, UU No. 16 Tahun 2011 tentang Bantuan Hukum serta UU No. 12 Tahun 1995 tentang Pemasyarakatan. Mulai tahapan proses pemeriksaan tersangka oleh pihak penyidik (kepolisian) seseorang tersangka telah dapat didampingi kuasa hukum atau advokat, hingga ke proses persidangan bahkan sampai terdakwa menjadi narapidana. Bantuan hukum dalam proses peradilan Indonesia telah diatur secara luas dalam arti semua tahapan proses peradilan para pencari keadilan dijamin oleh Undang-Undang tanpa kecuali, bagi terpidana

\footnotetext{
Artikel ini merupakan karya ilmiah mahasiswa pada Program Studi Magister S2 Ilmu Hukum Program Pascasarjana Universitas Udayana dan mengucapkan terima kasih kepada Prof. Dr. I Ketut Mertha, SH.,M.Hum dan Dr. I Gede Artha, SH.,MH selaku Pembimbing Tesis com
}

2 Mahasiswa Magister Ilmu Hukum Universitas Udayana Denpasar, Bali. Email : xinmanik@gmail.
\end{abstract}


dicanangkan berupa penyantunan seperti tersedianya upaya hukum secara luas dan disetiap jenjang proses peradilan, sarana remisi, cuti menjelang bebas, pelepasan bersyarat, resosialisasi, asimilasi dan lain-lain Peradilan pidana Indonesia dalam prosesnya dilakukan secara terpadu oleh penegak hukum dalam rangka proses yang adil guna terwujudnya tujuan hukum yang berkeadilan, bermanfaat dan terciptanya kepastian hukum bagi semua pencari keadilan berdasarkan "sistem" yang telah dianut yakni "sistem peradilan pidanaterpadu"

Kata Kunci : Bantuan Hukum, Penyantunan Terpidana, Sistem Peradilan

\section{PENDAHULUAN}

\subsection{Latar Belakang}

Berbicara soal pemberian bantuan hukum yang dimiliki setiap orang yang tersangkut sebagai tersangka, terdakwa dan terpidana adalah merupakan sebagai wujud hak bagi mereka yang telah dibawa sejak lakhir dan melekat selaku subyek hukum.

Adalah merupakan tugas negara untuk menjamin hak-hak mereka sebagai warga negaranya, seperti Indonesia yang menyatakan diri sebagai negara demokrasi yang berlandaskan atas hukum, sudah menjadi konsekuensi logis untuk melindungi semua rakyatnya dalam segala aspek kehidupan. Hal tersebut telah tertuang seperti tersurat dalam pembukaan UUD 1945 alinea IV yang menyatakan, "kemudian dari pada itu untuk membentuk suatu pemerintah negara Indonesia yang melindungi segenap bangsa Indonesia .... dan seterusnya.

Kemudian penjabaran dan pernyataan akan perlindungan hak- hak warga negara oleh pembukaan UUD 1945 itu dituangkan dalam pasal-pasal UUD 1945, Undang- Undang Organik di bawahnya dan sebagainya. Berkait dengan salah satu hak yang dimiliki dan diberikan negara kepada setiap orang adalah hak untuk memperoleh bantuan hukum bila mereka terlibat suatu perkara.

Secara yuridis normatif perlindungan akan hak warga negara di bidang hukum tertuang dalam Pasal 27 ayat (1) UUD 1945 yang menyatakan "segala warga negara bersamaan kedudukannya di dalam hukum dan pemerintahan dan wajib menjunjung hukum dan pemerintahan itu dengan tidak ada kecualinya". Secara lebih konkrit wujud perlindungan akan hukum secara merata bagi setiap warga negara Indonesia, tampak melalui perumusan Pasal 4 ayat (1) Undang-

Undang Nomor 48 Tahun 2009 tentang Kekuasaan Kehakiman yang merumuskan (1) pengadilan mengadili menurut hukum dengan tidak membeda-bedakan orang, pernyataan bunyi pasal ini merupakan bentuk pengakuan adanya persamaan akan hukum bagi setiap orang di depan hukum (dikenal dengan asas equality before the law). 
Salah satu wujud implementasi asas persamaan dimuka hukum ini adalah melalui bentuk bantuan hukum itu bagi setiap orang (terutama bagi orang miskin yang dapat diperolehnya tanpa bayar) atau (pro bono publico). ${ }^{3}$ Ini sebagai wujud penerapan Pasal 34 UUD 1945 di dalamnya menegaskan bahwa fakir miskin menjadi tanggung jawab negara.

Untuk perlindungan dan bantuan hukum bagi tersangka, terdakwa, terpidana bahkan setelah mereka kembali ke tengah-tengah masyarakat sebagai warga negara biasa, haruslah melalui mekanisme proses yang diatur dan masuk ke dalam sistem peradilan pidana terpadu (integrated criminal justice system). Bantuan hukum serta penyantunan bagi terpidana merupakan satu subsistem dari kerangka dalam sistem peradilan terpadu itu secara utuh. Dan masing- masing sub sistem ini ditangani mulai di tingkat penyidikan oleh penyidik (Polisi), penuntutan oleh Jaksa, persidangan oleh Hakim, dan peran Advokat atau Penasihat Hukum mulai dari awal (penyidikan hingga berakhirnya terdakwa diperiksa di persidangan sampai adanya putusan yang bersifat tetap (nikracht van geweijsde).

Kemudian setelah terdakwa menjadi terpidana maka merupakan tugas dan tanggung jawab Lembaga

Frans Hendra Winarta, 2000, Bantuan Hukum Suatu Hak Asasi Manusia Bukan Belas Kasihan. Penerbit PT. Elex Media Komputindo, Gramedia, Jakarta, 2000, hlm.vii.
Pemasyarakatan (Lapas) untuk berperan membinanya. Setelah mereka bebas dari Lembaga Pemasyarakatan barulah tugas masyarakat ikut berperan aktif menerima kembali kehadiran mereka tanpa harus lagi berprasangka memberikan stigma buruk terhadap bekas nara pidana tersebut.

Tugas para aparat penegak hukum yang berperan dalam pelaksanaan sistem peradilan pidana secara terpadu (Polisi, Jaksa, Hakim, Advokat, Lembaga Pemasyarakatan) masing-masing telah memiliki dasar kewenangan bertindak, seperti Polisi diatur oleh Undang-Undang No. 2 Tahun 2002, Kejaksaan oleh UndangUndang No. 16 Tahun 2004, hakim oleh Undang-Undang No. 49 tahun 2009, Undang-Undang No. 48 Tahun 2009 serta Undang-Undang No. 3 Tahun 2009, Lembaga Pemasyarakatan diatur oleh Undang- Undang No. 12 Tahun 1995 Dan terakhir UndangUndang Advokat No. 18 Tahun 2003, disertai dengan Undang - Undang No. 16 Tahun 2011 tentang Bantuan Hukum.

Secara keseluruhan semua aparat penegak hukum di atas menyelenggarakan penegakan supremasi hukum (supremacy of law) secara terpadu, dan mengemban pelaksanaan sistem peradilan pidana terpadu (integrated criminal justice system), salah satunya sebagai sub sistem unsurnya adalah melalui pencanangan dan pelaksanaan bantuan hukum serta tindak lanjut hingga penyantunan bagi terpidananya, 
sebagai wujud sistem peradilan pidana yang harus dilaksanakan secara terpadu hingga tuntas.

Secara teknis operasional bantuan hukum ini merupakan tugas dan tanggung jawab dari advokat atau penasehat hukum (dengan berbagai wadah institusinya), dan Lembaga Bantuan Hukum (negeri maupun swasta) baik di tiap Perguruan Tinggi Negeri atau Swasta yang ada di Fakultas Hukumnya, serta pihak swasta seperti kalangan Lembaga Swadaya Masyarakat (LSM).

Bantuanhukumsebagaisalah satu sub sistem penunjang terlaksananya sistem peradilan pidana semestinya dilaksanakan secara terpadu bagi Indonesia atas landasan dan sasaran KUHAP sudah semestinya bantuan hukum yang diberikan layanannya baik oleh advokat, penasehat hukum ataupun organisasi Lembaga Bantuan Hukum pada Perguruan Tinggi Negeri/Swasta serta kalangan berbagai Lembaga Swadaya Masyarakat, masih tampak banyak kendala yang merintanginya.

\subsection{Perumusan Masalah}

Diantaranya yang menjadi pokok permasalahan sehubungan judul di atas tampak rumusan masalah seperti berikut:

1. Apakah pemberian akan bantuan hukum bagi tersangka, terdakwa dan terpidana sudah masuk dalam kerangka sistem peradilan pidana Indonesia?
2. Apakah Advokat dan Lembaga Bantuan Hukum (LBH) sudah berperan secara optimal khususnya dalam penyantunan bagi terpidana?

\section{METODE PENELITIAN}

\subsection{Jenis Penelitian}

Karya tulis ini tergolong kedalam jenis penelitian hukum normatif atau penelitian hukum kepustakaan, karena penelitian hukum ini dilakukan dengan cara meneliti bahan kepustakaan (library research) yang terdiri dari bahan hukum primer dan ditunjang oleh bahan hukum sekunder.

Menurut Soerjono Soekanto dan Sri Mamudji, penelitian hukum normatif atau kepustakaan tersebut mencakup:

1. Penelitian terhadap asas-asas hukum.

2. Penelitian terhadap sistematik hukum.

3. Penelitian terhadap taraf sinkronisasi vertikal dan horizontal.

4. Perbandingan hukum.

5. Sejarah hukum ${ }^{4}$

Sehubungan dengan klasifikasi tersebut di atas maka penelitian hukum normatif ini menyangkut penelitian taraf sinkronisasi vertikal atas disharmonisasi norma yang ada. Dengan meneliti beberapa undangundang seperti Undang-undang No.

4 Soerjono Soekanto dan Sri Mamudji, 2001, Penelitian Hukum Normatif, PT. Raja Grafmdo Persada, Jakarta, hlm. 14 
8 Tahun 1981 (KUHAP), Undangundang No. 48 Tahun 2009 (Undangundang Kekuasaan Kehakiman), Undang-Undang No. 18 Tahun 2003 (Undang-Undang Advokat) dan Undang - Undang No. 16 Tahun 2011 tentang Bantuan Hukum. Khusus menyangkutpemberianbantuanhukum dan penyantunan bagi terpidana.

\subsection{Metode Pendekatan}

Sesuai dengan karakteristik dan sifat penelitian normatif(kepustakaan), maka dalam penelitian mi akan memakaibeberapa metode pendekatan, diantaranya:

- $\quad$ The Statue Approach pendekatan perundang-undangan.

- The Analitical and Conseptual Approach (pendekatan analisis konsep hukum).

\subsection{Sumber Bahan Hukum}

Penelitian hukum bersifat normatif, maka jenis bahan hukum yang lazim dipergunakan adalah :

a. Bahan-bahan Hukum Primer.

b. Bahan-bahan hukum sekunder.

c. Bahan-bahan hukum tersier ${ }^{5}$

Sehubungan dengan penelitian hukum normatif ini maka memakai sumber bahan hukum dari :

1. Bahan Hukum primer, seperti:

- Undang-undang No.

8 Tahun 1981 tentang KUHAP.

Ronny Hamijoyo Soemantri, 1998, Metode Penelitian Hukum dan Jurimetri, Ghalia Indonesia, Jakarta, hlm. 11-12.
- Undang-undang No. 48 Tahun 2009 tentang Kekuasaan Kehakiman

- Undang-undang No. 18 Tahun 2003 tentang Advokat

- Undang-undang No. 16 Tahun 2011 tentang Bantuan Hukum

2. Bahan hukum sekunder, yakni memberikan penjelasan mengenai bahan hukum primer.

3. Bahan hukum tersier, dalam hubungan penelitian ini menyangkut seperti kamus atau ensiklopedi.

\subsection{Metode Pengumpulan Bahan Hukum}

Penelitianiniuntukpengumpulan bahan hukum memakai metode sistematis, yakni berupa pengumpulan bahan peraturan perundang-undangan.

\subsection{Teknik Analisis Bahan Hukum}

Menggunakan teknis analitis seperti:

- $\quad$ Teknik diskripsi

- $\quad$ Teknik interpretasi

- $\quad$ Teknik evaluasi

- $\quad$ Teknik argumentasi

- $\quad$ Teknik sistematisasi

- $\quad$ Metode konstruksi hukum

\section{HASIL DAN PEMBAHASAN}

Penelitian disini hanya menampilkan kajian kualitatif atas bantuan hukum dan penyantunan terpidana. 


\subsection{Pengertian Bantuan Hukum}

Untuk mencermati apa sebenarnya pengertian bantuan hukum itu, akan dikutip beberapa pengertian bantuan hukum seperti :

a. Adnan Buyung Nasution antuan hukum dalam pengertiannya yang luas dapat diartikan sebagai upaya untuk membantu golongan yang tidak mampu dalam bidang hukum, upaya ini mempunyai tiga aspek yang saling berkaitan yaitu aspek perumusan aturan-aturan hukum, aspek pengawasan terhadap mekanisme untuk menjaga agar aturan-aturan itu ditaati, dan aspek pendidikan masyarakat agar aturan-aturan itu dihayati ${ }^{6}$.

b. Clarence J. Diaz

Bantuan hukum adalah segala bentuk pemberian layanan oleh kaum profesi hukum kepada khalayak di dalam masyarakat dengan maksud untuk menjamin agar tidak ada seorang pun di dalam masyarakat yang terampas haknya untuk memperoleh nasihat-nasihat hukum yang diperlukan hanya oleh karena sebab tidak dimilikinya sumber daya finansial yang cukup ${ }^{7}$ c. Todung Mulya Lubis

Bantuan hukum adalah salah satu upaya untuk mengisi hak asasi manusia bagi lapisan termiskin rakyat $^{8}$

d. Dalam Lokakarya Bantuan Hukum Tingkat Nasional Tahun 1978 menyatakan bahwa, bantuan hukum merupakan kegiatan pelayanan hukum yang diberikan kepada golongan yang tidak mampu (miskin) baik secara perorangan maupun kepada kelompok-kelompok masyarakat tidak mampu secara kolektif ${ }^{9}$

Dari beberapa pengertian di atas tentang bantuan hukum, dapat dipetik unsur-unsur essensialnya yang menyangkut :

- $\quad$ Berupa layanan akan hak setiap orang.

- Menyangkut terutama kehidupan rakyat miskin.

Tersangkut suatu masalah di bidang hukum.

Diberikan oleh kalangan profesi hukum.

- Pembentukan, pelaksanaan dan pengawasan aturan hukum oleh masyarakat.
Adnan Buyung Nasution, 1988, Bantuan Hukum di Indonesia. LP3ES, Jakarta, hlm.8. Clarence J. Diaz, 2001, Research on Legal Service and Provertv : It's Relevance to the Design of I egal Ser;ices Programs in Develoving Countries". (Dalam Bambang Sunggono : Bantuan Hukum dan Hak Asasi Manusia, Mandar Maju, Bandung, hlm. 10.
T. Mulya Lubis, 1986, Bantuan Hukum dan Kemiskman Struktural. LP3ES, Jakarta, 1986, hlm. 9.

9 Abdul Hakim Garuda Nusantara, 1981, Bantuan Hukum dan Kemiskinan Struktural. Prisma No. I, Januari 1981, hlm 40. 
- Unsur pendidikan hukum terutama sejak saat dilakukan terhadap masyarakat terutama penangkapan dan/atau penahanan membina kesadaran hukum berhak menghubungi dan meminta setiap orang. bantuan penasihat hukum."

Pasal 37 berbunyi : "Dalam

3.2. Landasan Hukum Pengaturan Bantuan Hukum

Perihal bantuan hukum termasuk di dalamnya prinsip equality before the law dan access to legal counsel, dan dalam hukum positif Indonesia telah diatur secara jelas dan tegas dalam berbagai peraturan perundangundangan seperti inisalnya:

1. Pasal 27 ayat (1) UUD 1945 yang menegaskan bahwa setiap warga negara bersamaan kedudukannya di dalam hukum dan pemerintah wajib menjunjung hukum dan pemerintahan itu dengan tidak ada kecualinya.

2. Pasal 34 UUD 1945 yang menegaskan bahwa fakir miskin dan anak telantar merupakan tanggung jawab negara. Oleh karena itu dapat dikatakan bahwa bantuan hukum terhadap orang miskin merupakan kewajiban negara juga untuk memberikannya.

3. Undang-Undang Nomor 48 tahun 2009 tentang Kekuasaan Kehakiman.

Pasal 4 ayat (1) berbunyi : "Setiap orang yang tersangkut perkara berhak memperoleh bantuan hukum."

Pasal 36 berbunyi : "Dalam perkara pidana seorang tersangka memberi bantuan hukum tersebut dalam pasal 36 di atas, penasihat hukum membantu melancarkan penyelesaian perkara dengan menjunjung tinggi Pancasila, hukum, dan keadilan.

4. Pasal 54 Undang-Undang Nomor 8 tahun 1981 tentang Kitab Undang-Undang Hukum Acara Pidana menegaskan bahwa guna kepentingan pembelaan, tersangka atau terdakwa berhak mendapat bantuan hukum dari seorang atau lebih penasihat hukum selama dalam waktu dan pada setiap tingkat pemeriksaan, menurut tata cara yangditentukan dalam undangundang ini.

\subsection{Bantuan Hukum Dalam Kerangka Sistem Peradilan Pidana Terpadu (Integrated Criminal Justice System).}

Sistem peradilan pidana yang dikonsepkan oleh KUHAP menuju pada sistem keterpaduan diantara penegak hukum (polisi, jaksa, hakim dan penasihat hukum).

Dalam rangkaian proses meliputi tindakan mekanisme hukum seperti penyidikan., penuntutan dan persidangan. Secara sepintas berbicara sistem peradilan pidana baru tampak 
hanya tiga tahapan tersebut. Padahal sebenarnya berbicara sistem peradilan secara lebih luas apalagi dilaksanakan secara terpadu di dalam penanganan suatu kasus pidana jauh lebih luas, lebih rumit dan memerlukan berbagai keterlibatan peran serta institusi secara periodik dan berkelanjutan.

Sistem peradilan pidana terpadu (integrated criminal justice system) seperti yang diharapkan peradilan pidana Indonesia yang berjalan baru berjalan sebatas proses formal seperti penyidikan, penuntutan dan persidangan secara prosedural saja, sedang makna, keterpaduan dan peran keterlibatan institusi secara terpadu dan menyeluruh belum tampak seperti peran serta Lapas (Lembaga Pemasyarakatan, Advokat, LSM dan masyarakat luas belum berperan aktif dalam rangkaian sistem tersebut.

Sehingga menurut pendapat Frans Hendra Winarta sistem peradilan pidana Indonesia belum terpadu. ${ }^{10}$ Seharusnya dalam berbicara mengenai penyeleng garaan peradilan pidana, fungsi yang seharusnya dijalankan oleh Sistem Peradilan Pidana Terpadu adalah sebagai berikut:

a. Melindungi masyarakat melalui upaya penanganan dan pencegahan kejahatan, merehabilitasi pelaku kejahatan dan, melakukan upaya inkapasitasi terhadap orang yang merupakan ancaman terhadap masyarakat.

\footnotetext{
${ }^{10}$ Frans Winarta, Op. Cit. hlm : 1
}

Vol. 5, No. 2 : 252 - 271

http://ojs.unud.ac.id/index.php/jmhu

b. Menegakkan dan memajukan the rule of law dan penghormatan pada hukum, dengan menjamin adanya due process dan KUHAP tampaknya masih jauh dari harapan. Hanya sementara ini sistem dan perlakuan yang wajar bagi tersangka, terdakwa dan terpidana, melakukan penuntutan dan membebaskan orang yang tidak bersalah yang dituduh melakukan kejahatan.

c. Menjaga hukum dan ketertiban.

d. Menghukum pelaku kejahatan sesuai dengan falsafah pemidanaan yang dianut.

e. Membantu dan memberi nasihat pada korban kejahatan (Malcoln Davies, Hazel Croall and Jane Tyrer) dalam : Harkristuti Harkrisnowo ${ }^{11}$

Sistem peradilan pidana terpadu yang menjadi harapan dan pedoman bagi Indonesia adalah Undang-Undang No. 8 Tahun 1981 (KUHAP).Di dalam penjelasan umum KUHAP angka 3 huruf $f$ tersurat bahwa "setiap orang yang tersangkut perkara wajib diberi kesempatan memperoleh bantuan hukum yang semata-mata diberikan untuk melaksanakan kepentingan pembelaan atas dirinya.

Sehubungan dengan asas pemberian bantuan hukum tersebut dalam kerangka sistem peradilan

11 Harkristuti Harkrisnowo, 2002, Sistem Peradilan Pidana Terpadu (Integrated Criminal Justice System). News letter, KHN-Komisi Hukum Nasional Republik Indonesia, hlm : 10 . 
pidana terpadu, dimana bantuan hukum merupakan salah satu sub sistem yang berperan menunjang keberhasilan bekerjanya seluruh komponen-komponen sub sistem yang ada, maka bantuan hukum ini sangat memegang peran penting di dalam bekerjanya proses sistem yang ada. Apalagi para penegak hukum sekarang ini masih cenderung menerapkan Crime Control Model (CCM) dari pada Due Process Mode (DPM) dalam penegakan supremasi hukum (Law Enforcement) untuk Due Process of Law (proses hukum yang adil).

Yang menurut Herbert L. Packer kedua bentuk (CCM dan DPM) itu disebut dua model proses kriminal (Two models of the criminal process will let us perceive the normative antinomy at the heart of the criminal law). ${ }^{12}$ atau dua model dalam proses kriminal sebagai gambaran normatif yang saling berbeda sasaran dan sebagai jantungnya dalam kejahatan.

Dalam dua model (CCM dan DPM) inilah sub sistem bantuan hukum yang diperankan oleh advokat atau penasihat hukum masuk di dalamnya sebagai komponen penunjang dalam proses bekerjanya sistem peradilan pidana mulai dari tingkat penyidikan sampai tingkat persidangan bahkan sampai terpidana selesai menjalani pidananya di Lembaga Pemasyarakatan.

12 Herbert L. Packer, 1968, The Limits of The Criminal Sanction. Stamford University Press, Stamford California, First Published, p. 153.
Vol. 5, No. $2: 252$ - 271

http://ojs.unud.ac.id/index.php/jmhu
Walaupun kedua model Crime
Control Model (CCM) dan Due

Process Model (DPM) sama-sama didasarkan pada Due Process of Law, tetapi CCM lebih mengutamakan efisiensi serta percaya pada kinerja yang profesionalisme dari penegak hukum. Sehingga peran advokat/ penasihat hukum kurang diperlukan kehadirannya. Sedangkan dalam DPM karena bekerjanya melihat suatu kemungkinan terjadinya human error, maka peran advokat diperlukan untuk mengecek kembali (cek and recek), sehubungan dengan proses DPM ini kinerjanya akan penuh rintangan.

Dua model proses dalam sistem peradilan pidana (CCM dan DPM) ini memberikan warna serta diperankan oleh advokat. Karena kedua sistem ini tidak tertutup kemungkinan secara bersamaan penerapannya masuk dalam satu kasus baik itu CCM maupun DPM. Kalau digambarkan dalam proses yang diperankan oleh masingmasing penegak hukum tampak seperti: penyidik akan berperan sebagai pencari fakta administratif untuk menuju sasaran menghukum tersangka (factual guilt), sedangkan jaksa mencari legal guilt ${ }^{13}$

Peran hakim semestinya sekarang setelah terjadi perubahan atas Undang-Undang No. 14 tahun 1970 dengan Undang-Undang No. 48 tahun 2009 tentang Pokok-pokok Kekuasaan Kehakiman sudah bersifat independen

Frans Hendra Winarta, Op. Cit. hlm.98 
dan imparsial dari campur tangan pemerintah. Namun pada kenyataan belum sepenuhnya mandiri.

Begitu halnya peran dan misi advokat dalam memberikan jasa bantuan hukum belum sesuai dengan tujuan awal kelahiran bantuan hukum ini yakni benar-benar akan membantu rakyat miskin yang buta hukum. Kondisi saat sekarang advokat/ penasihat hukum lebih dominan menjalankan perannya sebagai profit oriented ketimbang menjalankan misi kemanusiaannya. Padahal di dunia barat bantuan hukum merupakan bagian profesi advokat dalam rangka pro bono publico, sifatnya prodeo (demi Tuhan), tidak dipungut bayaran (fee) karena disediakan untuk orang miskin dan oleh karena itu bersifat non komersial kecuali dipungut biaya untuk ongkos administratif ${ }^{14}$

Penerapan asas equality before the law (persamaan dimuka hukum) harus dikedepankan khusus bagi masyarakat miskin dalam pemberian jasa bantuan hukum ini sesuai perintah Pasal 27 jo Pasal 34 UUD 1945.

Bantuan hukum sebagai bagian dari profesi advokat diatur dalam Eigth United Nations Congress on the Preventions of Crime and the Treatment of fenders bagian B. Other justruments adopted by the congress tepatnyapada bagian 3 basic principles on the role of lawyers tentang acces to lawyers and legal services. Menurut dokumen ini pemerintah mempunyai

\footnotetext{
Frans Hendra Winarta, Op. Cit. hlm: 132.
}

kewajiban untuk menyediakan dana yang cukup untuk memberikan jasa hukum bagi orang miskin dan orang yang memerlukan karena posisinya yang lemah.

Pemerataan distribusi pemberian jasahukuminipenting demi terciptanya masyarakat yang adil, dimana setiap orang dijamin dan dilindungi hak asasinya terutama perolehan jasa bantuan hukum dari advokat atau Lembaga Bantuan Hukum lainnya.

KUHAP yang mencanangkan perlindungan martabat manusia dilengkapi dengan tujuh asas umum dan tiga asas khusus, antara lain bantuan hukum dimasukkan sebagai perlindungan terhadap hak asasi seseorang (dalam rangka perwujudan asas equality before the law).

Rincian kesepuluh asas perlindungan hak serta harkat manusia oleh KUHAP terdiri dari asas-asas umum berikut ini:

1. Perlakuan yang sama dimuka hukum tanpa diskriminasi apapun;

2. Praduga tidak bersalah

3. Hak untuk memperoleh kompensasi (ganti rugi) dan rehabilitasi;

4. Hak untuk mendapat bantuan hukum;

5. Hak kehadiran terdakwa dimuka pengadilan;

6. Peradilan yang bebas dan dilakukan dengan cepat, dan sederhana

7. Peradilan yang terbuka untuk umum, serta asas-asas khusus; 
8. Pelanggaran atas hakhak individu (penangkapan, penahanan, penggeledahan, dan penyitaan) harus didasarkan pada undang-undang dan dilakukan dengan surat perintah (tertulis);

9. Hak seseorang tersangka untuk diberi tahu tentang persangkaan dan pendakwaan I terhadapnya, dan

10. Kewajiban pengadilan untuk mengendalikan putusan putusannya ${ }^{15}$

Semua asas di atas yang dituangkan dalam KUHAP menjiwai 'sistem peradilan pidana (terpadu) seperti yang diharapkan, khusus point (4), yang menggariskan hak untuk mendapat bantuan hukum yang terakumulasi ke dalam Crime Control Model (CCM) dan Due Process Model (DPM) dalam realitas proses dalam arti prosedur hukum acara mulai diberikan dari tingkat penyidikan sampai persidangan. Hal tersebut secara jelas tersurat dalam Pasal 54 KUHAP :

"Guna kepentingan pembelaan, tersangka atau terdakwa berhak mendapat bantuan hukum dari seorang atau lebih penasihat hukum selama dalam waktu dan pada setiap tingkat pemeriksaan, menurut tata cara yang ditentukan dalam undang- undang ini.

Mardjono Reksodiputro, 1997, Hak Asasi Manusia Dalam Sistem Peradilan Pidana. Buku Ketiga, Pusat Pelayanan Keadilan dan Pengabdian Hukum Universitas Indonesia, hlm 37-38.
Mencermati rumusan Pasal 54 tersebut dihubungkan dengan bantuan hukum ini pada rangkaian sistem peradilan pidana terpadu, belum tampak akan peran dan misi bantuan hukum pada posisi rehabilitasi terpidana yang telah berada dalam Lembaga Pemasyarakatan, terlebih lagi setelah kembali ke tengah - tengah masyarakat. Peran sub sistem institusi seperti Lembaga Pemasyarakatan dan masyarakat belum tampak dalam rangkaian sistem peradilan pidana terpadu dalam KUHAP tersebut.

Sebagai realisasi Pasal 54 akan bantuan hukum tanpa membedakan status tersangka / terdakwa (sebagai implementasi asas equality before the law) terhadap rakyat yang tergolong miskin atau kurang mampu dalam perkara pidana pemerintah (Indonesia) memberikan anggaran bagi mereka termasuk pemberi jasa bantuan hukum, dengan ketentuan lebih lanjut seperti berikut:

- Pelaksanaan bantuan hukum ini dimuat dalam Surat Keputusan Menteri Kehakiman Republik Indonesia Nomor 02.UM.09.08 tahun 1980 tertanggal 1 Juni 1980 tentang Petunjuk Pelaksanaan Bantuan Hukum dan kemudian dengan Keputusan Menteri Kehakiman Republik Indonesia Nomor: M.01. UM.08.10 tahun 1981 tertanggal 5 Nopember 1981 tentang Perubahan dan Perbaikan Keputusan Menteri Kehakiman 
Republik Indonesia Nomor : M.02.UM.09.03 tahun 1980 tentang Petunjuk Pelaksanaan Bantuan Hukum, yang pokoknya ditentukan sebagai berikut:

1. Pemberian bantuan hukum diselenggarakan melalui Badan Peradilan Umum cq Pengadilan Tinggi dan Pengadilan Negeri.

2. Bantuan hukum diberikan kepada tertuduh yang kurang mampu/tdak mampu, yang dibuktikan dengan :

a. Surat keterangan dari kepala desa, atau

b. Surat keterangan dari camat, atau

c. Surat keterangan dari kepala polisi, atau

d. Surat keterangan dari kepala kejaksaan negeri, atau

e. Surat keterangan dari kantor sosial.

Bantuan hukum diberikan kepada tertuduh dalam hal tindak pidana:

a. Yang diancam dengan pidana lima tahun penjara atau lebih, seumur hidup atau pidana mati;

b. Yang diancam dengan pidana kurang dari lima tahun, tetapi perkara tersebut menarik perhatian masyarakat luas.

Ketua majelis hakim setelah berkonsultasi dengan ketua pengadilan negeri menunjuk seorang atau lebih pemberi bantuan hukum dan menunjuk nama diberikan surat penetapan ketua majelis;

Uang bantuan hukum diberikan oleh Bendaharawan pengadilan negeri yang berada di bawah pengawasan ketua pengadilan negeri ${ }^{16}$

Secara universal pula pengakuan akan asas equality before the law telah tertanam ketentuannya pada Basic Principles on die Role of Lawyers yang diadopsi secara konsensus dalam Kongres PBB kedelapan mengenai Prevention of Crime and the Treatment of Offenders pada 1990 dan disahkan Majelis Umum PBB kemudian. Prinsip pertama dari Basic Principles on the Role of Lawyers menyatakan:

"Every one arrested or detained (whether or not on a criminal charge) and every one facing a criminal charge (wheter or not detained) bas the right to the assistance of legal counsel".

"Siapapun yang ditangkap atau ditahan (baik atas tuduhan melakukan tindak pidana atau tidak) dan siapapun yang menghadapi tuduhan melakukan tindak pidana (baik ditahan atau tidak) berhak

16 Martiman Prodjohamidjojo, 1984, Komentar Atas KUHAP. Cetakan Kedua, Pradnya Paramita, Jakarta, hlm. 46. 
untuk mendapatkan bantuan advokat". ${ }^{17}$

Prinsip ini telah diadopsi KUHAP lewat ketentuan pasal 69 (Bab VII-Bantuan Hukum) yang dirumuskan seperti berikut:

"Penasihat hukum berhak menghubungi tersangka sejak saat ditangkap atau ditahan pada semua tingkat pemeriksaan menurut tata cara yang ditentukan dalam undang-undang itu."

Di dalam mekanisme proses bekerjanya sistem peradilan pidana (pada model Crime Control Model (CCM), penyidik dalam langkah tindakannya cenderung menerapkan CCM ini, peran bantuan hukum melalui advokat ataupun penasihat hukum tidak begitu penting, yang dicari disini efisiensi waktu, tenaga dan pikiran, kebenaran semu yang dicari lebih dominan oleh penyidik. Tidak jarang pada jaman berlakunya H1R (Stb 1941 No : 44) tersangka dikejar dengan gencar untuk memperoleh pengakuan tersangka, dibawah teror dan intimidasi baik fisik maupun psikis oleh penyidik, sehingga pengakuan yang diperoleh adalah semu, tidak sesuai dengan kebenaran yang hakiki. Sistem pemeriksaan inquissitoir ini memperburuk citra aparat penyidik

$17 \quad$ Binziad Kadafi dkk, 2002, Advokat Indonesia Mencari Legitimasi (Studi Tentang Tanggung Jawab Profesi Hukum di Indonesia). Pusat Studi Hukum dan Kebijakan Indonesia, Jakarta. ketika itu, dan ini akan terungkap. Setelah terdakwanya diperiksa di tingkat persidangan. Karena ketika dipersidanganlah terdakwa baru didampingi penasihat hukun/advokat, maka sering BAP (Berita Acara Pemeriksaan) diingkari terdakwa atau menolak isi BAP yang telah ditanda tangannya di depan penyidik. Bentuk CCMiniakan bertolakbelakang dengan sistem kerja DPM, yang dalam proses penyidikan (seperti dianut KUHAP) telah mengarah sistem pemeriksaan yang lebih terbuka, lebih menghargai asas presumption of innosence dan telah mengusahakan adanya peran advokat/penasihat hukum selaku kontrol kinerja sistem DPM ini.

Sistem kerja DPM dalam KUHAP ditingkat penyidikan menggunakan pola pemeriksaan inquissitoir yang diperlunak, tersangka sudah boleh didampingi penasihat hukum (walaupun sifatnya pasif).

Sedang di tingkat persidangan kinerja DPM akan lebih transparan lagi, karena peran advokat/penasihat hukum benar- benar telah berperan aktif mulai memiliki hak mengajukan eksepsi, pledoi, upaya hukum dan sebagainya, sebagai wujud bantuan hukum baik sifatnya non profit oriented maupun profit oriented terhadap posisi kliennya.

Penekanan bantuan hukum oleh advokat atau oleh penasihat hukum baik dari kalangan profesi swasta maupun misi organisasi seperti LKBH (Lembaga Konsultasi 
dan Bantuan Hukum), atau bentuk organisasi lainnya, sasaran utama yang diemban KUHAP adalah ditujukan pada kalangan masyarakat kurang mampu atau miskin dan buta hukum. Hal ini seperti dinyatakan dalam penegasannya Martiman Prodjohamidjojo yang menekankan pada :

1. Asas yang terpenting bagi orang yang kena perkara ialah asas untuk memperoleh bantuan hukum. Undang-undang memberikan bantuan hukum, sejak saat ditangkap atau ditahan pada semua tingkat pemeriksaan, agar seseorang tersangka/terdakwa diperlakukan sesuai dengan martabatnya sebagai manusia dan selama belum terbukti kesalahannya harus dianggap tidak bersalah.

2. Pada bab VII maka bantuan hukum ini diberikan oleh penasihat hukum. Istilah penasihat hukum telah diintrodusir sebagai pengganti istilah: advokat, pengacara, yakni seorang yang memenuhi persyaratan berdasarkan undangundang untuk memberikan bantuan hukum.

3. Undang-undang memberikan bantuan hukum tidak didasarkan kepada siapa yang dapat membayar penasihat hukum, akan tetapi didasarkan kepada sila perikemanusiaan, yang merupakan hak asasi manusia. Karena itu telah disediakan dana
Vol. 5, No. $2: 252$ - 271

http://ojs.unud.ac.id/index.php/jmhu

bantuan bagi golongan miskin atau golongan yang tidak mampu untuk dapat menikmati bantuan hukum dengan cuma-cuma. ${ }^{18}$

Sebagai suatu komparasi dalam hal peran negara serta advokat untuk memberikan jasa bantuan hukumnya terhadap warga yang tidak mampu, seperti Amerika, negara juga menganggarkan operasional biaya untuk itu. Bila warganya ada terlibat kasus pidana, maka ia berhak minta bantuan negara dari segi biaya untuk berperkara. Dan termasuk untuk jasa pemberi bantuan hukum itu diporsikan sebesar 25 persen (bagi pengacara) dan jumlah total biaya yang ditentukan besarnya sesuai bobot perkaranya. Hal ini diakui oleh seorang pengacara senior Amerika Mr. David C Davenport, Jr Esquire.

Selanjutnya dikatakannya bahwa bantuan hukum di Amerika diberikan kepada kliennya sejak ia diinterogasi polisi sampai diperiksa di pengadilan. Bila tersangkanya harus mendapat dan harus didampingi pengacara menurut ketentuan keharusan undang-undang, namun hal ini diabaikan, maka bila diketahui kemudian, terhadap hal seperti itu dapat menghentikan proses jalannya pemeriksaan terhadap terdakwa, dan bahkan akan membatalkan putusan hakim, ${ }^{19}$

18 Martiman Prodjohamidjojo, Op Cit, hlm. 52.

19 David C. Davenport, Jr. Esquire, Tradisi Standar dan Teknik Layanan Jasa Hukum di Amerika. Judul ceramah yang disampaikan atas kerjasama CCLE-UNUD bekerjasama dengan University of San Fransisco School of Law) di Grand Bali Beach Hotel, Denpasar, 12 April 2003. 
(susunan kalimat dari rangkaian penulis) dengan mencari inti/sari penceramah. Hal seperti ini bagi Indonesia (KUHAP) belum mengatur seperti itu. Walaupun ada syarat seseorang tersangka/terdakwa harus didampingi advokat/penasihat hukum karena terlibat kasus dengan ancaman pidana 5 (lima) tahun atau lebih, yang semestinya menurut KUHAP harus ada pendamping. Advokat/Penasihat Hukum dari sejak ia diperiksa oleh penyidik, namun sering penyidik mengabaikan keharusan tersebut. Hal ini diakibatkan berbagai faktor seperti penyidik kemungkinan sengaja mengabaikannya, demi cepatnya pemeriksaan (di sini peran sistem Crime Control Model (CCM) yang dominan mewarnai sistem peradilan pidana Indonesia, ketimbang peran bekerjanya sistem Due Process Model (DPM). Atau kemungkinan lain tersangka/terdakwa sama sekali menolak akan hak yang dimilikinya untuk didampingi penasihat hukum.

Tidak menerimanya kehadiran penasihat hukum oleh tersangka/ terdakwa juga akibat beberapa faktor seperti misalnya:

- Tersangka/terdakwa tidak mengerti akan peran penasihat hukum atau bantuan hukum bagi posisi dirinya bila berhadapan dengan hukum.

- Tersangka/terdakwa selalu membayangkan bahwa dalam berperkara dan didampingi penasihat hukum akan membayar biaya mahal.

\begin{abstract}
Tersangka/terdakwa tidak tahu bila ia tidak mampu membayar ada prosedur dan negara/ pemerintah akan menyediakan bantuan hukum ini.

Tersangka/terdakwa merasa yakin dan mampu akan mengatasi sendiri akan kasus yang dihadapinya.

- Tersangka/terdakwa merasa pasrah akan dirinya dan semuanya diserahkan kepada kebijaksanaan hakim.
\end{abstract}

Bagi Indonesia bantuan hukum terutama untuk golongan rakyat tidak/ kurang mampu, begitu pula untuk setiap tersangka/terdakwa yang terlibat dalam suatu kasus pidana, secara yuridis formal telah diatur dalam :

Pasal 56

(1) Dalam hal tersangka atau terdakwa disangka atau didakwa melakukan tindakan pidana yang diancam dengan pidana mati atau ancaman pidana lima belas tahun atau lebih atau bagi mereka yang tidak mampu yang diancam dengan pidana lima tahun atau lebih yang tidak mempunyai penasihat hukum sendiri, pejabat yang bersangkutan pada semua tingkat pemeriksaan dalam proses peradilan wajib menunjuk penasihat hukum bagi mereka.

(2) Setiap penasihat hukum yang ditunjuk untuk bertindak sebagaimana dimaksud dalam 
ayat (1), memberikan bantuannya dengan cuma-cuma.

Bantuan hukum yang diberikan ini cuma-cuma, dan pengaturan pelaksanaan dana bantuan diatur dengan Keputusan Menteri Kehakiman Republik Indonesia nomor : M.02. UM.09.08 tahun 1980 dan nomor : M.01.UM.08.10 tahun 1981. (realisasi Pasal 54 KUHAP).

\subsection{BentukBantuanHukum Dalam Penyantunan Terpidana}

Sebagai rangkaian dari sub sistem, bantuan hukum dalam pengertian yang lebih luas lagi dalam menunjang sistem peradilan pidana terpadu (integrated criminal justice system) tampaknya belum ada menunjukkan peran sampai pada tingkat penyantunan terpidana atau setelah terpidana berada dalam binaan Lembaga Pemasyarakatan.

Padahal keberhasilan sistem peradilan pidana ditentukan pula pada pintu akhir ini dari tahapan seseorang setelah menjalani rangkaian proses sebelumnya menjalani status hukum sebagai tersangka-terdakwa-terpidana dan bebas kembali ke masyarakat menjadi warga biasa.

Sebenarnya peran besar bantuan hukum yang mesti masih diberikan adalah ikut mengarahkan pembinaan terpidanasemasihmenjalanibimbingan di dalam Lembaga Pemasyarakatan, kemudian ikut serta pula menuntun setelah mereka bebas ke tengah-tengah
Vol. 5, No. $2: 252$ - 271

http://ojs.unud.ac.id/index.php/jmhu

habitatnya semula di masyarakat, aktif berperan serta meresosialisasikan keberadaan mereka setelah bebas.

Kendala terbesar yang dihadapi mantan terpidana / narapidana adalah justru setelah akan melangkah meninggalkan pintu Lembaga Pemasyarakatan, dihadapan mereka terkadang bayangan cemohan, kesan ketidakrelaan masyarakat akan menerima kembali kehadiran mereka. Stigma jahat yang dilontarkan terhadapnya akan membuat mantan penghuni Lembaga Pemasyarakatan ini akan berpikir, berbuat, bersikap serba canggung, timbul rasa kurang percaya diri, bahkan ingin tetap tinggal dalam Lembaga Pemasyarakatan (penulis sempat pernah mewawancarai mantan narapidana ketiganya bekas pembunuh yang masing-masing dipidana penjara 15 tahun, 10 tahun dan 12 tahun (I Nengah Rerod, I Gede Karsi dan Ni Nyoman Tompel) asal masingmasing Dusun Gumung Tenganan Pageringsingan, Desa BungayaKarangasem).

Di dalam Lembaga Pemasyarakatan hanya petugas pembina Lembaga Pemasyarakatan yang dominan bekerja di dalam sistem peradilan pidana, yang walaupun secara teori peran Hakim Pengawas dan Pengamat Putusan sesuai asas dalam KUHAP yang ditugaskan kepada Ketua Pengadilan Negeri masih harus aktif terlibat di dalam membina, mengawasi terpidana hingga masa pidana yang dijalaninya berakhir. 
Pada saat-saat inilah peran bantuan hukum sama sekali tidak tampak diatur oleh sistem. Peran CCM/DPM telah berhenti saat hakim mengetukkan palunya di pengadilan. Di lain sisi sistem peradilan pidana terpadu mengharapkan sistem CCM/ DPM yang salah satu sub sistem di dalamnya yakni bantuan hukum yang diperankan oleh advokat/penasihat hukum atau apapun istilahnya dipentingkan perannya hingga terpidana benar- benar diterima di tengah-tengah masyarakat sampai tidak lagi cap jahat (stigma jahat) disandang olehnya.

Adapun wujud penyantunan bagi terpidana yang disediakan oleh negara tampak dalam kebijakankebijakan pemerintah yang bisa atau dapat dinikmati bagi si nara pidana yang aturannya telah dibakukan dan memiliki kepastian hukum seperti misalnya berupa:

1. Undang Undang Republik Indonesia Nomor 12 Tahun 1995 tentang Pemasyarakatan dengan segala teknis dan ruang lingkupnya;

2. Peraturan Pemerintah Republik Indonesia Nomor 31 Tahun 1999 tentang Pembinaan dan Pembimbingan Warga Binaan Pemasyarakatan dengan semua lingkup dan penjabarannya;

3. Peraturan Pemerintah Republik Indonesia Nomor 32 Tahun 1999 tentang Syarat dan Tata Cara Pelaksanaan Hak Warga Binaan
Pemasyarakatan seperti hak di bidang pendidikan, kesehatan, kerohanian;

4. Keputusan Menteri Kehakiman Republik Indonesia Nomor : M.03-PK.04.02 Tahun 1991 tentang Cuti Mengunjungi Keluarga Bagi Narapidana;

5. Peraturan Menteri Kehakiman Republik Indonesia Nomor: M.01-PK..10 Tahun 1989 tentang Asimilasi, Pembebasan Bersyarat dan Cuti Menjelang Bebas;

6. Surat Mahkamah Agung Republik Indonesia Nomor : MA/Pemb/3290/1984 mengenai Petunjuk tentang Permohonan Banding yang diajukan melalui Kepala Lembaga Kemasyarakatan;

7. Surat Mahkamah Agung Republik Indonesia Nomor : MA/Pemb/3291/84 mengenai Petunjuk tentang Permohonan Banding yang Diajukan Melalui Kepala Lembaga Pemasyarakatan;

8. Keputusan Menteri Kehakiman Republik Indonesia Nomor : M.01-PR.07.03 Tahun 1983 tentang Organisasi dan Tata Kerja Lembaga Pemasyarakatan;

9. Keputusan Menteri Kehakiman Republik Indonesia Nomor : M.03-UM.01.06 Tahun 1983 tentang Penetapan Lembaga Pemasyarakatan Tertentu Sebagai Rumah Tahanan Negara; 
10. Peraturan Menteri Kehakiman

Republik Indonesia Nomor : M- 04-UM.01.06 Tahun 1985 tentang Tata Cara Penempatan, Perawatan Tahanan dan Tata Tertib Rumah Tahanan Negara;

11. Standard Minimum Rules for the Treatment of Prisoners;

12. Peraturan-peraturan Standar Minimum bagi Perlakuan terhadap Narapidana;

13. Kumpulan Prinsip-prinsip untuk Perlindungan Semua Orang yang Berada di bawah Bentuk Penahanan Apapun atau Pemenjaraan;

14. Keputusan Presiden Republik Indonesia Nomor 174 Tahun 1999 Tentang Remisi;

15. Undang-Undang

Republik Indonesia Nomor : 22

Tahun 2002 Tentang Grasi.

Semua peraturan perundangundangan di atas diterapkan dalam menunjang bekerjanya sistem peradilan pidana khusus di Lembaga Pemasyarakatan terhadap terpidana dalam rangka mempersiapkan diri terpidana untuk keluar dan kembali menyatu ke tengah-tengah lingkungan keluarga/masyarakat.

Dapat digambarkan bahwa di dalam sistem peradilan pidana pada tingkat/ proses akhir ini, bantuan hukum wujudnya sudah berbeda dengan pemberian bantuan hukum pada tingkat penyidikan dan persidangan, pada tingkat status terpidana di
Lembaga Pemasyarakatan, bantuan hukum berwujud luas, lebih abstrak, dan bukan diperankan oleh advokat / Penasehat Hukum. Tetapi langsung oleh negara atau pemerintah lewat berbagai kebijakan pidana (criminal policy) baik berbentuk kebijakan penal maupun non penal.

\section{PENUTUP \\ 4.1 Simpulan}

Darirangkaianjudulmenyangkut tentang Perlindungan dan Bantuan Hukum bagi Tersangka/Terdakwa maupun wujud penyantunan terhadap terpidana dalam kerangka Sistem Peradilan Pidana Terpadu yang dituju oleh KUHAP, setelah dikaji dengan permasalahan yang diangkat, maka dapat disimpulkan hal-hal seperti berikut :

1. Bantuan hukum yang merupakan salah satu sub sistem penunjang dari sistem peradilan pidana yang hendak menjadi harapan dan tujuan sistem peradilan pidana Indonesia (secara terpadu) atau dikenal dengan istilah integrated criminal justices system, sudah masuk di dalam kerangka sistem peradilan pidana Indonesia yang bernapaskan dua bentuk proses kriminal yakni Crime Control Model (CCM) dan Due Process Model (DPM) guna menuju Due Processof Law, sebagai wujud pelaksanaan asas equality before the law dan pemberian bantuan hukum yang seluas-luasnya 
bagi tersangka-terdakwa dan terpidana.

2. Bantuan hukum yang diperankan oleh Advokat atau Penasihat Hukum baru berperan nyata hanya pada tingkat penyidikan dan persidangan terhadap tersangka / terdakwa, sedang proses selanjutnya pelaksanaan bantuan hukum secara konkrit yang diperankan Advokat / Penasihat Hukum belum tampak di tingkat Lembaga Pemasyarakatan(LAPAS) maupun setelah terpidana keluar / bebas dari Lembaga Pemasyarakatan realisasi bantuan hukum terhadap terpidana berwujud penyantunan yang diberikan oleh pemerintah (negara) seperti pemberian cuti mengunjungi keluarga bagi nara pidana, pemberian cuti menjelang bebas, pembebasan bersyarat, asimilasi, pemberian remisi, dan pemberian grasi, yang kesemuanya ini diatur dengan peraturan perundangundangan.

\subsection{Saran}

1. Agar advokat dalam memberi bantuan hukum pada para justisiabel tidak membedabedakan perlakuan

2. Agar pemerintah melalui Departemen Hukum dan Hak Asasi Manusia secara optimal dapat memberikan santunan pada narapidana atau warga binaan / anak didik pemasyarakatan

\section{DAFTAR PUSTAKA}

Adnan Buyung Nasution, 1988, Bantuan Hukum di Indonesia. LP3ES, Jakarta. Binzard Kadafi, dkk, 2002, Advokat Indonesia Mencari Legitimasi (Studi Tentang Tanggung Jawab Profesi Hukum di Indonesia) Pusat Studi Hukum dan Kebijakan Indonesia, Jakarta.

Bambang Sunggono, Aries Hartanto, 2001, Bantuan Hukum dan Hak Asasi Manusia. Mandar Maju, Bandung.

David C. Davenport, Jr. Esquire, 2003, Tradisi.Standar dan Tehnik Layanan Jasa Hukum di Amerika (Ceramah yang disampaikan atas kerjasama CCLE-UNUD bekerjasama dengan University of Sanfransisco School of Law) di HBB-Sanur-Denpasar.

Frans Hendra Winarta, 2000, Bantuan Hukum Suatu Hak Asasi Manusia Bukan Belas Kasihan. Penerbit: PT. Elex Media Komputindo, Gramedia, Jakarta.

Harkristuti Harkrisnowo, 2002, Sistem Peradilan Pidana Terpadu (Integrated Criminal Justice System), Newsletter, Komisi Hukum Nasional Republik Indonesia. Jakarta.

Hakim Garuda Nusantara A, 1981, Bantuan Hukum dan Kemiskinan Struktural (Dalam Majalah Prisma No. 1 Januari 1981).

Mardjono Reksodiputro, 1997, Hak Asasi Manusia Dalam Sistem 
Peradilan Pidana. Buku III, Pusat Pelayanan Keadilan dan Pengabdian Hukum UI, Jakarta. Martiman Prodjohamidjojo, 1984, Komentar Atas Kitab UndangUndang Hukum cara Pidana (KUHAP). Cetakan Kedua, Pradnya Paramita, Jakarta.

Packer, HL, 1968, The Limits of the Criminal Sanction. Stanford University Press, California, First Published, Amerika, p. 153.

Todung Mulya Lubis, 1986, Bantuan Hukum dan Kemiskinan Struktural. LP3ES, Jakarta.

Yudha Pandu, 2001, Klien dan Penasihat Hukum Dalam Perspektif Masa Kini. Cetakan Pertama, PT. Abadi-Jakarta.

Universal Declaration on the Independence of Justice, World Confrence on the Independence of Justice, CIJI Bulletin, Montre al, October 1983.

UU No. 48 Tahun 2009 tentang Kekuasaan Kehakiman

UU No. 8 Tahun 1981 tentang KUHAP

UU No. 18 Tahun 2003 tentang Advokat

UU No. 16 Tahun 2011 tentang Bantuan Hukum

UU No. 12 Tahun 1997 tentang Lembaga Pemasyarakatan 